The Egyptian Journal of Hospital Medicine (July 2014) Vol. 56, Page 280-288

\title{
Occult Hepatitis C Virus Infection in Haemodialysis Unit: A Single-center Experience
}

\author{
Abdel Hamid A. Serwah ${ }^{1}$, Waleed S. Mohamed ${ }^{1}$, Mohamed Serwah ${ }^{1}$, Awateif Edreis ${ }^{2}$, Ahmad El \\ Zaydi $^{3}$ \\ Internal Medicine Department, College of Medicine, Taif University, KSA, ${ }^{1}$ Tropical medicine \\ Department, College of Medicine, Taif University, KSA, ${ }^{2}$ and Consultant of Nephrology, KAASH, \\ $\mathrm{KSA}^{3}$
}

Author of Correspondence: Abdelhamid Serwah. Internal Medicine Department, College of Medicine, TaifUniversity.E-mail: abdelhamidserwah@yahoo.com. Mobile: 00966/557849852

\begin{abstract}
Background \& Aims: Detection of hepatitis C virus RNA in peripheral blood mononuclear cells (PBMC) and/or hepatocytes in the absence of HCV RNA in serum, designated as 'occult HCV infection', has been a matter of controversy in the recent years. Occult hepatitis C virus (HCV) infection has not been investigated in haemodialysis patients. We investigated for the first time the prevalence of occult HCV infection in large cohorts of chronic hemodialysis (CHD) patients in a single heamodialysis center at Al-Taif, KSA.

Methods: We enrolled 84 CHD patients, whose sera are negative for HCV markers. HCV RNA was tested in PBMC using a sensitive commercial real time assay. In this study, real-time PCR was used to test for the presence of genomic HCV-RNA in peripheral blood mononuclear cells of all of these patients. For comparison, 20 patients on HD with evidence of chronic hepatitis $\mathrm{C}$ virus infection were included as a control group.

Results: In CHD patients, occult HCV infection, determined by the presence of genomic HCV-RNA in peripheral blood mononuclear cells (PBMNCs), was found in $13.4 \%$ of the patients; $83 \%$ of these patients had ongoing HCV replication, indicated by the presence of HCV-RNA. Patients with occult HCV infection had spent a significantly longer time on heamodialysis and had significantly higher mean alanine aminotransferase levels during the 3 months before study entry. Compared to CHCV patients, those with occult HCV have less elevated bilirubin, AST and ALT.

Conclusions: The prevalence of occult HCV infection was moderate in our CHD patients, and it did not appear to be clinically relevant. Further studies in other geographic populations with high HCV endemicity are required to clarify the significance of occult HCV infection in these patient groups.

Abbreviations

HCV, Hepatitis C Virus ; antibody against HCV; PBMC, peripheral blood mononuclear cells; rRT-PCR, real time reverse transcriptase polymerase chain reaction; $\mathrm{CHD}$, chronic hemodialysis.
\end{abstract}

\section{Keywords}

Occult hepatitis C; HCV; PBMCs; Peripheral blood mononuclear cells; Prevalence; Hemodialysis; HCV RNA; Anti-HCV.

\section{Introduction}

Hepatitis $\mathrm{C}$ virus (HCV) infection is a worldwide infection associated with an increased disease burden due to liver cirrhosis and considerable mortality. It is estimated that about 170 million people, $3 \%$ of the world's population, are infected with HCV. ${ }^{1,2}$ So far, six major genotypes (HCV-1 to HCV-6) have been described, each containing multiple subtypes, ${ }^{3}$ with significant differences in their global distribution and prevalence. ${ }^{4}$ Despite screening of blood products for anti-HCV and implementation of precaution measures, $\mathrm{HCV}$

infection is still a major problem in heamodialysis (HD) units. ${ }^{5,6}$ Chronic infection with hepatitis $\mathrm{C}$ virus (HCV) is a serious public health problem associated with increased morbidity and mortality. It can lead to the development of cirrhosis and even hepatocellular carcinoma., ${ }^{7,8}$ The prevalence of HCV is high among Saudi patients, ${ }^{9}$ and the prevalence in patients with chronic renal failure

DOI: $10.12816 / 0005575$ 
maintained on heamodialysis ranged from $52.5 \%$ to $72.3 .{ }^{10-13}$

A new entity of HCV infection was first described in 2004 in patients with persistently elevated liver function tests and who were anti$\mathrm{HCV}$ and serum HCV RNA negative. ${ }^{14}$ Despite the absence of conventional HCV markers, 57\% of these patients had HCV RNA in the liver and so this clinical situation was termed "occult $\mathrm{HCV}$ infection". Moreover, it was proven that the antigenomic HCV RNA strand could be detected also in the hepatocytes of a high proportion of those patients with occult $\mathrm{HCV}$ infection, thus indicating an active viral replication. ${ }^{14}$ Occult HCV infection has also been described in other different clinical settings. ${ }^{15-20}$

Occult HCV infection has also been found in heamodialysis patients who were persistently anti-HCV and serum HCV RNA negative but with abnormal values of liver enzymes $^{21}$ in the family setting of patients with occult hepatitis $\mathrm{C}^{22}$ and even in healthy subjects with normal alanine aminotransferase levels and no clinical evidence of liver disease. ${ }^{22}$

Since HCV was replicated in the liver and PBMCs of patients with occult HCV infection, it was speculated that it should exist as circulating viral particles, but at such low levels that the virions could not be detected even using the most sensitive rRT-PCR technique. Viral RNA is detectable in the PBMCs and in ultracentrifuged serum of patients with occult $\mathrm{HCV}^{9,21}$ and anti-core $\mathrm{HCV}$ tested by a non-commercial enzyme-linked immunosorbent assay (ELISA) is also found in a substantial proportion of these patients. ${ }^{21}$ So, when occult HCV infection is suspected and a liver biopsy is not available for HCV RNA detection, the diagnosis can be made by testing, with a highly sensitive rRT-PCR technique, for the presence of viral RNA in PBMCs (that identifies between $60 \%-70 \%$ of the cases) ${ }^{14}$, or in ultracentrifuged serum (that allows identification of occult $\mathrm{HCV}$ in around $60 \%$ of the patients). ${ }^{23,24}$

\section{Aims of the work:}

To the best of our knowledge, the prevalence of occult hepatitis $\mathrm{C}$ virus infection among patients on regular heamodialysis in
Saudi Arabia is not available. So, we tried in this work to (1) study the existence of occult HCV infection by testing for genomic HCV-RNA in PBMC of heamodialysis patients and (2) describe the characteristics of these patients compared to overt HCV patients who are also on regular heamodialysis. The overall aim of this study is to know if there is a need to regularly check for occult HCV in the blood of patients who are subjected to regular heamodialysis or not. This will reduce the potential transmission of $\mathrm{HCV}$ to other $\mathrm{HCV}$ free patients on heamodialysis.

\section{Methodology}

\section{Subjects and Methods}

\section{Study design: cross sectional analytic study}

\section{Setting and participants}

We enrolled one cohort of patients on chronic heamodialysis (CJD) and one control group as follows:

\section{CHD patients}

Eighty four clinically stable adult patients undergoing chronic haemodialysis at single dialysis center in Al-Taif city between March 2013 and May 2014.

\section{Positive controls}

Twenty contemporaneous anti-HCVpositives, HCVRNA-positive with chronic HCV infection, who are on regular heamodialysis. Patients showing the following criteria were included in the study: negative serological evidence of $\mathrm{HCV}$ infection ( $\mathrm{HCV} / \mathrm{Ab}$ and HCV/RNA). Those patients and 20 controls were subjected to the following further investigations: CBC, liver enzymes (ALT, AST, and AP), and total serum bilirubin, serum creatinine and blood urea.

\section{Work-up}

Clinical Examination: Selected patients were subjected to thorough clinical examination stressing on the liver status. Abdominal ultrasound was done with emphasis on liver and splenic status and evidence of assets.

Laboratory methods: A peripheral blood sample for PBMC separation (about $10 \mathrm{ml}$ ) was collected at enrollment into two tubes containing EDTA. Plasma and PBMCs were separated from $5 \mathrm{ml}$ of whole blood and stored immediately at $-80^{\circ} \mathrm{C}$. PBMCs were isolated using the FicollHypaque density gradient (Lonza, Walkersville, 
Maryland, USA). Sera were tested for liver function tests, renal function tests and electrolytes. The presence of $\mathrm{HBsAg}$, anti-HCV antibodies and HCV-RNA in serum samples were checked for HCV-RNA in PBMC was checked using rRT-PCR. Anti-HCV testing in serum was performed by chemiluminescentmicroparticle immunoassay (CMIA) (Architect system, ABBOTT Diagnostic Division, Abbot Park, Illinois, USA). HCV-RNA extraction and detection in serum and PBMCs

Total RNA isolated from $150 \mu \mathrm{L}$ of either serum or PBMCs of the same individuals using the SV Total RNA Isolation System (Promega, Madison, Wisconsin, USA) according to the manufacturer's instructions. The real-time PCR assay was performed using commercial, TaqMan hydrolysis probe based, real time PCR HCV detection Kit (Liferiver, Shanghai, China) in Eppendorf Mastercycler ${ }^{\circledR}$ ep realplex2. The detection of the amplified amplicon was performed in fluorimeter channel FAM with the fluorescent quencher BHQ1. Amplification reactions were performed in a volume of $25 \mu \mathrm{l}$ containing $2.5 \mu \mathrm{l}$ of DNA template, $21.5 \mu \mathrm{l}$ reaction mix, $0.4 \mu \mathrm{l}$ enzyme mix, $1 \mu \mathrm{l}$ internal control according to the manufacturer's instructions.

According to the results of HCV lab. Examination our included patients were classified into 3 groups:

Group 1: 12 patients with occult HCV

Group 2: 72 patients who are negative for both occult $\mathrm{HCV}$ and chronic $\mathrm{HCV}$

Group 3: 20 chronic (classical) HCV

Sequencing of selected samples

One-step RT-PCR amplification of the 5' Untranslated Region (UTR5') sequences was performed using one step RT PCR (KomaBiotech, Korea) in a total $50-\mu 1$ reaction volume using $5 \mu \mathrm{l}$ of the extracted RNA, 0.6 $\mu$ Mforward 5'-

GAAAGCGTCTAGCCATGGCGTTAGT-

$3^{\prime}$ and reverse 5'CTCGCAAGCACCCTATCAGG-

3 'oligonucleotides. ${ }^{25}$ Samples were incubated at $50^{\circ} \mathrm{C}$ for $30 \mathrm{~min}$, and $95^{\circ} \mathrm{C}$ for $15 \mathrm{~min}$. DNA amplification was performed for 35 cycles each consisting of $94^{\circ} \mathrm{C}$ for $15 \mathrm{~s}, 50^{\circ} \mathrm{C}$ for $30 \mathrm{~s}, 72^{\circ} \mathrm{C}$ for $40 \mathrm{~s}$. The last cycle was followed by a $7 \mathrm{~min}$. Extension step at $72^{\circ} \mathrm{C}$. Amplicons were purified and analyzed by ethidium bromide agarose gel electrophoresis. Samples showing a band of the $241 \mathrm{bp}$ were excised from the gel and amplicon was purified using a gel extraction kit (KomaBiotech, Korea) for further analysis by DNA sequencing in both directions using the sense and antisense amplification primers (Macrogen Inc., Korea).

\section{Sequence alignment and phylogenetic analyses \\ Viral sequences aligned using} CLUSTAL W software. Neighbor-joining (NJ) analyses performed using mega 4.1, software, with pairwise distances estimated using Kimura two-parameter distances.

\section{Ethical considerations}

A permission of the heamodialysis unit directors was taken. The study protocol got approval from the Ethics Committee of the Taif University. The study protocol also received approval from the research ethics committee of the King AbdelAziz Specialized Hospital (KAASH). Informed consents were taken from all patients before including in the study. The consent assured that subjects have the right to withdraw from the study at any time without compromising their rights for treatment and clinical care. All conducted tests are noninvasive. Sampling was minimized and samples of blood were taken on a single occasion to avoid needless repeated venous punctures. The data of the patients are confidentially treated.

\section{Statistical analyses}

All data were introduced to Excel program. Statistical analyses were performed by SPSS package release 18.0. Comparisons between groups were made by Student's t test, the Mann-Whitney, and ANOVA "when needed" for continuous variables, and by either the Chi square test or Fisher's exact test for categorical data.

\section{Results}

We studied 84 consecutive patients with end stage renal disease (ESRD) on maintenance heamodialysis whose sera were negative for 
$\mathrm{HCV} / \mathrm{Ab}, \mathrm{HCV} / \mathrm{RNA}$ and HBsAg from March 2013 to March 2014 for prevalence of occult HCV infection.

The demographic, clinical features, etiology, history of blood transfusion and time on heamodialysis of groups $(1 \& 2)$ are described in table 1 . The mean age was 44.3 (24-64) and 48 (28-72) years, respectively, with a male accounted for $65 \%$ and $58 \%$ in the two groups. The clinical presentations were generalized swelling in $12 \%$ and $14 \%$, decreased urine output by $23 \%$ and $26 \%$, hypertension by $35 \%$ and $42 \%$ and altered sensation in $8 \%$ and $11 \%$ respectively. The mean duration on maintenance HD was 38 (25-58) and 23 (18-47) months in patients with and those without the occult $\mathrm{HCV}$ infection $(p<0.05)$. Fifty two $\%$ and $34 \%$ of patients with and without occult $\mathrm{HCV}$ respectively received blood transfusions $(\mathrm{p}<$ 0.05). No statistically significant differences were found between the 2 groups regarding hemoglobin, blood urea and creatinine.

As shown in table 2, on study entry, mean AST, ALT and AP levels were, respectively, 66.4 (58-135), 68.5 (52-141), and 76.5 (58.6-155.2) in occult HCV group and were 48.4 (38-125), $51.5(42-168)$ and $46.5(42.6-135.2)$ in the negative occult $\mathrm{HCV}$ group. The differences between these enzymes in the 2 groups were statistically significant ( $\mathrm{p}<0.05)$. HCV-RNA was found by strand-specific real-time PCR in PBMC of $10(83.3 \%)$ of 12 patients, indicating that they had an occult HCV infection.

As shown in tables $1 \& 3$, the etiologies of ESRD were nearly similar in the studied groups with the following order of frequency: diabetes mellitus, hypertension, glomerulopathy of unknown etiology and chronic post infectious glomerulonephritis. In about $8 \%$ of cases the etiology of ESRD was not identified. Comparison of occult HCV patients to those with "classical" $\mathrm{CHCV}$ infection are presented in tables (3\&4). The chronic (classical) hepatitis $\mathrm{C}$ patients were matched to those with occult $\mathrm{HCV}$ infection for age and gender. No differences regarding demographic, clinical or etiological factors were found between the two groups of patients. The biochemical characteristics of these patients are shown in table 4. The causes of ESRD in both groups of patients were nearly the same. There were statistically significant differences in liver function tests in the two studied groups with mild elevation in bilirubin, transaminases, and alkaline phosphatases in the $\mathrm{CHC}$ group compared with occult $\mathrm{HCV}$ group. No statistically significant differences between the two groups regarding hemoglobin, blood urea and creatinine.

\section{Discussion}

This is the first study investigating the frequency of occult $\mathrm{HCV}$ infection among the heamodialysis patients in Saudi Arabia to the best of our knowledge. Using a highly sensitive test for detection of viral RNA in PBMCs, we found a low to moderate prevalence of occult $\mathrm{HCV}$ infection in this group. The findings from the present study are the first to come from State of Al Taif. Heamodialysis patients presented high susceptibility to acquiring HCV if the clinics do not follow the universal precautions recommended by the Ministry of health authorities. According to these norms, patients should be evaluated every 6 months for $\mathrm{HCV}$ and other HCV markers. Patients who are reactive to $\mathrm{HCVAb}$ are sent to the yellow room (reserved for patients with HCVAb positive), while the seronegative individuals are then tested for anti-HBs. Nonetheless, detecting such patients in heamodialysis clinics is of prime importance in avoiding dissemination of the virus inside these units, given that patients with unidentified occult $\mathrm{HCV}$ may transmit this infection to other patients as they undergo their treatment alongside other heamodialysis patients who are susceptible to HCV. The repeated exposure to body fluids during dialysis procedures predisposes dialysis patients to nosocomial transmission of HCV. HCVRNA is detectable in the serum and peripheral blood mononuclear cells of these patients, thus indicating that active virus replication is occurring.

Information about occult $\mathrm{HCV}$ infection in patients on maintenance heamodialysis is limited. 14, 16, 17 The discrepancy in the reported incidence of occult HCV between several studies, including the present study $(16,17,24,25)$, could be due to several factors. One could be the differences in sensitivity of the methods used for detection of the virus genome (nested PCR 
versus quantitative real-time PCR). Small sample sizes in some of these studies may also be a factor. Another reason could be quantitative differences in the levels of HCV viremia during the course of the disease in different patient populations. This conclusion is based on data by some authors ${ }^{26}$ who examined repeated sera from the same patients for the presence of $\mathrm{HCV}$ RNA, and demonstrated inconsistent results with previously negative samples being positive for HCV RNA and vice versa, which suggests a fluctuating level of viremia in the course of the disease. There are also differences in the prevalence of $\mathrm{HCV}$ in the general population, according to geographic location, which can influence the prevalence of $\mathrm{HCV}$ infection among heamodialysis patients.

In the current research, the age of patients with occult HCV ranged (24 -64) years, with male predominance. This comes into agreement with that of others. ${ }^{14,27}$ According to the original report of occult $\mathrm{HCV}$ infection, ${ }^{14}$ all HD patients with HCV-RNA in PBMC must also have viral RNA in the liver. This could be verified in the patient who had an occult HCV infection and underwent a liver biopsy. Nevertheless, it should be stressed that detection of HCV-RNA in PBMC does not identify all cases with occult $\mathrm{HCV}$, so some of the HD patients without viral RNA in PBMC could have an occult HCV infection in liver; however, liver biopsy is not routinely recommended for HD patients except in a subset of cases (e.g., in renal transplant candidates, before starting antiviral therapy). Duration of HD was significantly longer in patients with occult HCV infection, compared to those who are negative HCVRNA in the PBMNCs, but it was still shorter than those with $\mathrm{CHCV}$ infection. Antecedents of blood transfusion were more in patients with occult HCV compared to negative patients for this infection, but still less in number if compared to patients with $\mathrm{CHCV}$ infection. This finding suggests the possible role of nosocomial transmission in the spread of occult $\mathrm{HCV}$, as reported in HD units for "classical" $\mathrm{HCV}$ infection. ${ }^{2,27}$

Aminotransferase levels (AST and ALT) were significantly higher in the group of patients with occult $\mathrm{HCV}$ infection compared to patients with negative HCVRNA in PBMNCs.
However, these enzymes were higher in chronic hepatitis $\mathrm{C}$, than that of occult $\mathrm{HCV}$ infection indicating that the cytolysis is more severe in these cases than in patients with occult HCV infection. As $\mathrm{HCV}$ proteins may be implicated in liver damage by either interfering with intracellular signaling pathways or by their recognition by the host immune system, ${ }^{28}$ the higher number of $\mathrm{HCV}$-infected hepatocytes could explain why patients with chronic hepatitis $\mathrm{C}$ have greater liver damage. Furthermore, this difference may be explained by the fact that patients with occult $\mathrm{HCV}$ infection have a more refined immunological control of HCV infection. Thus, it has been recently reported that the breadth of the cellular immune responses is different in the peripheral blood between chronic hepatitis $\mathrm{C}$ and occult HCV infection ${ }^{29,30}$

In some studies, it was found that aminotransferase levels were in concordance with histological damage of the liver. Necroinflammatory activity and fibrosis were detected more frequently in chronic hepatitis $\mathrm{C}$ than in occult HCV infection patients. ${ }^{22}$ So occult HCV infection seems to be a less aggressive form of the disease caused by HCV. However, in the same study liver cirrhosis was detected in a similar percentage $(4.4 \%)$ in occult $\mathrm{HCV}$ infection as that found in our population with chronic hepatitis C (7.2\%). The existence of occult $\mathrm{HCV}$ infection may potentially have significant consequences for this population. These include the risk of nosocomial transmission of the virus within heamodialysis units. Therefore, detection of occult HCV infection not uncovered by routine diagnostic methods may have an important bearing on the development of new screening strategies and therapeutic interventions for $\mathrm{HCV}$ infection in these patients. However, data on the prevalence of occult $\mathrm{HCV}$ are conflicting and sparse in these patients. If occult $\mathrm{HCV}$ infection does transmit HCV within dialysis units, then it seems that current measures to control the spread of HCV, although they don't incorporate routine PCR or neucleic acid technology, should be adequate. However, more information is needed about occult $\mathrm{HCV}$ in this setting. The current study has some strong and some weak points. The strengths of our study are, inclusion 
of positive control groups, use of a highly sensitive and validated commercial assay that is less prone to contamination and interference with cellular DNA or RNA, testing at a dedicated, single-site laboratory, comprehensive evaluation of multiple clinical factors and of patients with occult HCV infection and controls.

However, there are also some limitations that need to be mentioned. These include the inclusion of small cohort, absence of liver biopsies, as detection of HCV genome in the liver is the most accurate method for the diagnosis of occult $\mathrm{HCV}$ infection. However, it is reported that HCV RNA in PBMC has been demonstrated to be reliable for identifying patients with an occult $\mathrm{HCV}$ infection when a liver biopsy is not available; up to $70 \%$ of patients with occult HCV infection in liver have been found to have HCV RNA in PBMC ${ }^{14,22}$. Moreover, liver biopsy is an invasive procedure that may be associated with an increased bleeding risk in CHD patients. Other limitations of this study are: the small sample size used in this study, and that the samples were collected cross sectionally at one time point and sequential, repeated analysis of the PBMC at different time points was not performed. Therefore, it remains theoretically possible that some of the occult HCV infection may have been missed owing to the intermittent and fluctuating nature of $\mathrm{HCV}$ viremia ${ }^{31}$. However, repeated testing in such large numbers would not only have been time- and resource-consuming and challenging, but would also have little practical application for routine evaluation in a clinical setting. Lastly, analysis of quantitative viral load or genotyping in the samples positive for occult HCV could not be performed because of the limited amount of samples left and low levels of HCV RNA.

In conclusion, preliminary data suggest a moderate frequency of occult $\mathrm{HCV}$ infection in dialysis patients. Furthermore, there are no available data showing the virulence of this form of virus that is present in only PBMCs and not in the circulation. Additional more detailed studies are required to determine the real prevalence and the clinical consequences of this infection in dialysis patients. Also further studies in different geographic populations with high $\mathrm{HCV}$ endemicity are required to clarify the significance of occult $\mathrm{HCV}$ infection in these patient groups.

\section{References}

1. Shepard CW, Finelli L, Alter MJ (2005): Global epidemiology of hepatitis C virus infection. Lancet Infect Dis., 5:558-67.

2. Clarke B (1997): Molecular virology of hepatitis C virus. J Gen Virol., 78: 2397-410.

3. Bukh J, Miller RH, Purcell RH. (1995): Genetic heterogeneity of hepatitis $\mathrm{C}$ virus: quasispecies and genotypes. Semin Liver Dis., 15:41-63.

4. Bostan N, Mahmood T (2010): An overview about hepatitis C: a devastating virus. Crit Rev Microbiol., 36:91-133.

5. Fabrizi F, Lunghi G, Ganeshan SV, Martin P, Messa P (2007): Hepatitis $C$ virus infection and the dialysis patient. Semin Dial., 20: 416-22.

6. Barril G, Traver JA (2003): Decrease in the hepatitis $\mathrm{C}$ virus (HCV) prevalence in hemodialysis patients in Spain: effect of time, initiating HCV prevalence studies and adoption of isolation measures. Antiviral Res., 60: 129-34.

7. MohdHanafiah K, Groeger J, Flaxman AD, Wiersma ST (2013): Global epidemiology of hepatitis $\mathrm{C}$ virus infection: new estimates of agespecific antibody to HCV seroprevalence. Hepatology, 57:1333-42.

8. Moyer VA (2013): Screening for hepatitis $C$ virus infection in adults: US preventives services task force recommendation statement. Ann Intern MED., 159:349-57.

9. Abdel-Moneim, AS, Bamaga, MS, Abu-Elsaad, A.S., Shehab, GM, Farahat, FM (2012): HCV infection among Saudi population: High prevalence of genotype 4 and increased rate of viral clearance. PLOS ONE., 7 (1): e29781.

10. Karkar A (2007): Hepatitis C in dialysis units: the Saudi experience. Hemodial Int.,11: 354-67.

11.Al-Shohaib SS, Abdelaal MA, Zawawi TH et al. (1995): The prevalence of hepatitis $C$ virus antibodies among hemodialysis patients in Jeddah area, Saudi Arabia. Saudi J Kidney Dis Transplant., 6:128-31.

12. Bernieh B, Allam M, HalepotaAet al. (1995): Prevalence of hepatitis $\mathrm{C}$ virus antibodies in hemodialysis patients in Madinah Al-Munawarah. Saudi J Kidney Dis Transplant., 6:132-5.

13. Shaheen FAM, Huraib SO, Al-Rasheed Ret al. (1995): Prevalence of hepatitis $C$ antibodies among hemodialysis patients in the Western Province of Saudi Arabia. Saudi J Kidney Dis Transplant., 6:136-9.

14. Castillo I, Pardo M, Bartolomé J, OrtizMovilla N, Rodríguez-Iñigo $E$, de Lucas $S$, 
Salas C, Jiménez-Heffernan JA, Pérez-Mota A, Graus Jet al. (2004): Occult hepatitis $C$ virus infection in patients in whom the etiology of persistently abnormal results of liver-function tests is unknown. J Infect Dis., 189:7-14.

15. Radkowski M, Horban A, Gallegos-Orozco JF, Pawelczyk A, Jablonska J, Wilkinson J, Adair D, Laskus $T$ (2005): Evidence for viral persistence in patients who test positive for antihepatitis $\mathrm{C}$ virus antibodies and have normal alanine aminotransferase levels. J Infect Dis., 191:1730-3.

16. Fabrizi F, Martin P (2008): Occult Hepatitis C Virus Infection in Hemodialysis. J Am SocNephrol., 19:2248-50.

17. Barril G, Castillo I, Arenas MD, Espinosa M, Garcia-Valdecasas J, Garcia-Fernández N, González-Parra E, Alcazar JM, Sánchez C, Diez-BaylónJCet al. (2008): Occult hepatitis C virus infection among hemodialysis patients. J Am SocNephrol., 19:2288-92.

18. Radkowski M, Gallegos-Orozco JF, Jablonska J, Colby TV, Walewska-Zielecka B, Kubicka J, Wilkinson J, Adair D, Rakela J, Laskus T (2005): Persistence of hepatitis $C$ virus in patients successfully treated for chronic hepatitis C. Hepatology, 41:106-114.

19. Castillo I, Rodríguez-Iñigo E, López-Alcorocho JM, Pardo M, Bartolomé J, Carreño V (2006): Hepatitis $C$ virus replicates in the liver of patients who have a sustained response to antiviral treatment. Clin Infect Dis.,43:1277-83.

20.Pham TN, Coffin CS, Churchill ND, Urbanski SJ, Lee SS, Michalak TI (2012): Hepatitis C virus persistence after sustained virological response to antiviral therapy in patients with or without past exposure to hepatitis B virus. J Viral Hepat., 19:103-11.

21. Castillo I, Rodríguez-Iñigo E, Bartolomé J, de Lucas S, Ortíz-Movilla Net al. (2005): Hepatitis $\mathrm{C}$ virus replicates in peripheral blood mononuclear cells of patients with occult hepatitis C virus infection. Gut, 54: 682-88.

22.Pardo M, López-Alcorocho JM, RodríguezIñigo E, Castillo I, Carreño V (2007): Comparative study between occult hepatitis C virus infection and chronic hepatitis C. J Viral Hepat., 14: 36-40.

23. Carreño V (2006): Occult hepatitis $C$ virus infection: a new form of hepatitis C. World J Gastroenterol., 12: 6922-25.

24.Jain P, Nijhawan (2008): Occult hepatitis C virus infection is more common than hepatitis $\mathrm{B}$ infection in maintenance hemodialysis patients. World J Gastroenterology, 14 (14): 2288-9.

25. Murphy D, Willems B, Deschenes M, Hilzenrat $\mathrm{N}$, Mousseau R, et al. Use of sequence analysis of the NS5B region for routine genotyping of hepatitis $\mathrm{C}$ virus with reference to $\mathrm{C} / \mathrm{E} 1$ and 5 'untranslated region sequences. J ClinMicrobiol. 2007;45:1102-1112.

26. Lili KS, Dagmar P, Christian M (2000): Hepatitis B virus in sera and liver tissue of HBsAg negative DNA with chronic hepatitis C. J Hepatol., 3:785-90

27. Saad y, Zakaria S, Ramzy I, El RazikiMet al. (2011): Prevalence of occult hepatitis $C$ in Egyptian patients with non alcoholic fatty liver disease. Open Journal of Internal Medicine, 1: 337

28. Schneeberger PM, Keur I, van Loon AM, Mortier D, de Coul KO, van Haperen AV, Sanna, R, van Der Heijden TG, van Den Hoven H, van Hamersvelt HW, Quint W, van Doorn LJ (2000): The prevalence and incidence of hepatitis $\mathrm{C}$ virus infections among dialysis patients in the Netherlands: A nationwide prospective study. J Infect Dis., 182: 1291-9.

29. Shrivastava A, Manna SK, Ray R et al. (1998): Ectopic expression of hepatitis $\mathrm{C}$ virus core protein differentially regulates nuclear transcription factors. J Virol., 72: 9722-8.

30. Quiroga JA, Castillo I, Rodri'guez-Inigo E et al. (2004): HCV-specific cellular immune responses in patients with occult $\mathrm{HCV}$ infection in the liver. Hepatology, 40: 278A.

31. Baid-Agrawal, Schindler R, Reinke Pet al. (2014): Prevalence of occult hepatitis $C$ infection in chronic hemodialysis and kidney transplant patients. Journal of Hepatology, 60 (5), 928-33.

\section{ACKNOWLEDGMENTS}

The authors would like to thank the hemodialysis patients, authorities, and the staff of the dialysis centers King AbdelAziz Hospital that collaborated in the study, and Health authorities at A-Taif Governorate making this research possible.

\section{CONFLICT OF INTEREST}

The authors declare that there is no conflict of interest.

\section{FINANCIAL SUPPORT}

This study was supported by the University of Al Taif, KSA 
Table 1. Demographic and clinical parameters of patients on maintenance heamodialysis with and without occult HCV

\begin{tabular}{|l|c|c|c|}
\hline Parameter & $\begin{array}{c}\text { Occult HCV } \\
\mathbf{1 2}\end{array}$ & $\begin{array}{c}\text { Negative Occult HCV } \\
\mathbf{7 2}\end{array}$ & P value \\
\hline Male: cases (\%) & $8(66.7)$ & $42(58)$ & NS \\
\hline Clinical features, cases (\%) & $48(28-72)$ & NS \\
\hline Age in years, (range) & $44.3(24-64)$ & $22(31)$ & $<0.05$ \\
\hline History of blood transfusion, cases (\%) & $05(41.7)$ & $23(18-47)$ & $<0.05$ \\
\hline Time on hemodialysis (mo), mean (range) & $38(25-58)$ & $10(14.0)$ & NS \\
\hline Generalized swelling, cases (\%) & $02(16.7)$ & $20(28.0)$ & NS \\
\hline Oliguria, cases (\%) & $03(25.0)$ & $33(46.0)$ & NS \\
\hline Hypertension cases (\%) & $05(41.7)$ & $09(13.0)$ & NS \\
\hline Altered sensorium cases (\%) & $01(08.0)$ & $33(45.7)$ & NS \\
\hline Etiology, cases (\%) & $05(41.7)$ & $20(27.7)$ & NS \\
\hline Diabetes mellitus & $03(25.0)$ & $06(8.3)$ & NS \\
\hline Hypertensive nephropathy & $02(16.7)$ & $07(10)$ & NS \\
\hline Glomerulopathy, unknown & $01(08.3)$ & $06(8.3)$ & NS \\
\hline Chronic post infectious glomerulonephritis & $001(08.3)$ & & \\
\hline Others &
\end{tabular}

Values are mean (95\% confidence interval of the mean) or number

Table 2. Biochemical Parameters of Patients on Maintenance Haemodialysis with and without Occult HCV

\begin{tabular}{|l|c|c|c|}
\hline & $\begin{array}{c}\text { Occult HCV } \\
\mathbf{1 2}\end{array}$ & $\begin{array}{c}\text { Negative Occult HCV } \\
\mathbf{7 2}\end{array}$ & P value \\
\hline Laboratory parameters & & & \\
\hline Hemoglobin (mg/dL) values Mean (CI) & $8.6(7.8-11.2)$ & $9.2(7.6-11.3)$ & NS \\
\hline Urea (mg/dL) values Mean (CI) & $18.4 .(8.4-32.2)$ & $19.4 .(8.4-28.2)$ & $\mathrm{NS}$ \\
\hline Creatinine (mg/L) values Mean (CI) & $2.5(1.4-5.2)$ & $2.6(1.5-5.7)$ & $\mathrm{NS}$ \\
\hline Bilirubin (mg/L) values Mean (CI) & $2.8(1.8-4.5)$ & $1.5(1.2-3.5)$ & $<0.05$ \\
\hline AST (IU/l) mean (CI) & $66.4(58-135)$ & $48.4(38-125)$ & $<0.05$ \\
\hline ALT (IU/l) Mean (CI) & $58.5(52-141)$ & $51.5(42-168)$ & $<0.05$ \\
\hline AP (IU/L Mean (CI) & $76.5(58.6-155.2)$ & $46.5(42.6-135.2)$ & $\mathrm{NS}$ \\
\hline
\end{tabular}

Values are mean (95\% confidence interval of the mean) or number. AST, aspartate aminotransferase.ALT, alanine aminotransferase. AP, alkaline phosphatase 
Table 3. Demographic and clinical parameters of patients on maintenance heamodialysis with Occult and Overt HCV

\begin{tabular}{|l|c|c|c|}
\hline Parameter & Occult HCV & Overt HCV & P value \\
\hline Male: cases (\%) & $8(66.7)$ & $14(70)$ & Ns \\
\hline Clinical features, cases (\%) & \multicolumn{2}{|l|}{} \\
\hline Age in years, (range) & $44.3(24-64)$ & $41.7(22-60)$ & NS \\
\hline History of blood transfusion, cases (\%) & $05(41.7)$ & $12(60)$ & $<0.05$ \\
\hline Time on hemodialysis (mo), mean (range) & $23(18-47)$ & $38(25-58)$ & $<0.05$ \\
\hline Generalised swelling & $02(16.7)$ & $4(20)$ & NS \\
\hline Oliguria, Dyspnea & $03(25.0)$ & $6(30)$ & NS \\
\hline Hypertension & $03(25.0)$ & $6(30)$ & NS \\
\hline Altered sensorium & $05(41.7)$ & $8(40)$ & NS \\
\hline Etiology, cases (\%) & $05(41.7)$ & $8(40)$ & NS \\
\hline Diabetes mellitus & $03(25.0)$ & $6(30)$ & NS \\
\hline Hypertensive nephropathy & $02(16.7))$ & $2(10)$ & NS \\
\hline Glomerulopathy, unknown & $01(08.3)$ & $3(15)$ & NS \\
\hline Chronic post infectious glomerulonephritis & $01(08.3)$ & $1(5)$ & NS \\
\hline Others
\end{tabular}

Values are mean (95\% confidence interval of the mean) or number.

Table 4. Biochemical parameters of patients on maintenance heamodialysis with Occult and Overt HCV

\begin{tabular}{|l|c|c|c|}
\hline Parameter & $\begin{array}{c}\text { Occult HCV } \\
\mathbf{1 2}\end{array}$ & $\begin{array}{c}\text { Overt HCV } \\
\mathbf{2 0}\end{array}$ & P value \\
\hline Laboratory parameters & \multicolumn{3}{|c|}{} \\
\hline Hemoglobin $(\mathrm{mg} / \mathrm{dL})$ & $8.6(7.8-11.2)$ & $8.4(7.7-11.1)$ & $\mathrm{NS}$ \\
\hline Urea $(\mathrm{mg} / \mathrm{dL}))$ & $18.4 .(8.4-32.2)$ & $21.4 .3(8.7-32.5)$ & $\mathrm{NS}$ \\
\hline Creatinine $(\mathrm{mg} / \mathrm{L})$ & $2.5(1.4-5.2)$ & $2.7(1.5-5.2)$ & $\mathrm{NS}$ \\
\hline Bilirubin $(\mathrm{mg} / \mathrm{L})$ & $2.2(1.6-3.5)$ & $2.8(1.8-5.1)$ & $<0.05$ \\
\hline AST $(\mathrm{IU} / \mathrm{l})$ mean $(\mathrm{CI})$ & $66.4(58-135)$ & $87.4(55-178)$ & $<0.05$ \\
\hline ALT $(\mathrm{IU} / \mathrm{l})$ Mean $(\mathrm{CI})$ & $58.5(52-141)$ & $84.5(68-192)$ & $<0.05$ \\
\hline AP mean $(\mathrm{CI})$ & $66.5(58.6-155.2)$ & $76.5(62.6-165.2)$ & $\mathrm{NS}$ \\
\hline
\end{tabular}

Values are mean (95\% confidence interval of the mean) or number. AST, aspartate aminotransferase; ALT, alanine aminotransferase; AP, alkaline phosphatase. 